\title{
LOWER BIFIDOBACTERIA COUNTS IN ADULT PATIENTS WITH CELIAC DISEASE ON A GLUTEN-FREE DIET
}

\author{
Lisléia GOLFETTO ${ }^{1}$, Fernanda Duarte de SENNA ${ }^{1}$, Julia HERMES ${ }^{1}$, \\ Bruna Teles Soares BESERRA ${ }^{2}$, Franciane da Silva FRANÇA ${ }^{1}$ and \\ Flávia MARTINELLO3.
}

\begin{abstract}
Context - The ingestion of gluten is responsible for the symptoms of Celiac disease, but other environmental factors can also influence. Strains of the Bifidobacterium genus have been shown to afford protection against the inflammatory response and mucosal damage caused by gliadin peptides in vitro. Objective - This study was designed to compare the concentration of fecal bifidobacteria and $\mathrm{pH}$ of patients with celiac disease on gluten-free diet and control subjects in order to identify if the imbalance on fecal microbiota still remain during the treatment of celiac disease and identify the necessity of dietary supplementation with pre- or probiotics. Methods - It was analyzed the feces of 42 healthy subjects and 14 celiac patients. The bifidobacteria count in feces was done in selective medium BIM-25. Microscopic analysis of the colonies was performed by Gram stain. The identification of the genus Bifidobacterium was performed by determination of fructose-6-phosphate phosphoketolase. Fecal $\mathrm{pH}$ was measured using a pH meter. Results - The concentration of bifidobacteria per gram of feces was significantly higher in healthy subjects (controls) $\left(1.5 \pm 0.63 \times 10^{8} \mathrm{CFU} / \mathrm{g}\right)$ when compared to celiac patients $\left(2.5 \pm 1.5 \times 10^{7} \mathrm{CFU} / \mathrm{g}\right)$. The fecal $\mathrm{pH}$ was not different between celiac patients (7.19 \pm 0.521$)$ and controls (7.18 \pm 0.522$)$. Conclusion - These results suggest that with lower levels of bifidobacteria, celiac patients have an imbalance in the intestinal microbiota, regardless of $\mathrm{pH}$, even while on a gluten-free diet. This fact could favor the pathological process of the disorder.
\end{abstract}

HEADINGS - Bifidobacterium. Microbiota. Hydrogen-Ion concentration. Celiac disease. Gluten-free diet.

\section{INTRODUCTION}

Celiac disease (CD) is a multifactorial disorder that involves interactions between genetic and environmental factors ${ }^{(27)}$. Environmental factors incriminated include early life gluten exposure, short duration of breastfeeding, intestinal infections and changes in microbiota $^{(9)}$.

Changes in the composition of intestinal microbiota in CD have been demonstrated in children ${ }^{(3,5,21)}$. Meanwhile, we have no knowledge of studies evaluating the balance of microbiota in adults with $C D$ under treatment (diet), which is presumed that there is an equal number of bifidobacteria in relation to individuals without $\mathrm{CD}$.

The presence of bifidobacteria in the gastrointestinal tract has been associated with a variety of beneficial health effects ${ }^{(4,16)}$. The resistance provided by these bacteria to the host against pathogens represents its direct effect on human health. On the other hand, their indirect effect is observed through the interaction with the lymphoid tissue and villi ${ }^{(26)}$.

Although the precise mechanisms of probiotics in the intestinal tract are not fully elucidated, they are targets of detailed in vivo and in vitro scientific research and seem to occur in a specie-specific form. Strains of the Bifidobacterium genus have been shown to afford protection against the inflammatory response and mucosal damage caused by gliadin peptides. In vitro studies have indicated that bifidobacteria strains reduces the production of inflammatory cytokines (IFN- $\gamma$ and TNF- $\alpha$ ) and increases IL-10. Protective effects were seemed by increasing the number of goblet cells in the small intestine, which were reduced by the presence of gliadin, IFN- $\gamma$, and enterobacteria. In relation to cytokine production, B. bifidum enhanced the production of chemotactic factors (MCP-1) and inhibitors of metalloproteinases (TIMP-1), which could contribute to gut mucosal protection. In addition, strains of different Lactobacillus species exerted 
inductive rather than suppressive effects on both the innate and adaptive immunity. L. casei strain could enhance both mucosal and systemic T-cell-mediated responses to gluten. Furthermore to immunomodulatory effects, B. longum also showed to contribute to the hydrolysis of gliadin peptides during intestinal digestion by reducing the presence of toxic amino acid sequences and their adverse effects, reducing the cytotoxicity of gliadin peptides and their ability to activate the NF-kB subunits and TNF- $\alpha$ and IL- $1 \beta$ production. Another research group reported that a strain of $B$. lactis, but not of L. fermentum, inhibited the gliadin-induced increase of epithelial permeability in vitro ${ }^{(26,27)}$.

In this context, this study was designed to compare the concentration of fecal bifidobacteria and $\mathrm{pH}$ of patients with celiac disease and control subjects in order to identify if the imbalance on fecal microbiota still remains during the treatment of celiac disease and identify the necessity of dietary supplementation with pre- or probiotics.

\section{METHODS}

\section{Subjects}

Two groups of adults were included in this study: (Group 1) 14 celiac patients, with previous positive serology markers and with previous signs of enteropathy by duodenal biopsy examination, but actually on a gluten-free diet for at least 2 years; without showing clinical symptoms of the disease, (Group 2) 42 control healthy adults without known food intolerance. None of volunteers included in the study were treated with antibiotics, pre- or probiotic for at least 3 months before the sampling time.

\section{Fecal pH and Bifidobacteria}

For isolation and quantification of bifidobacteria and fecal $\mathrm{pH}$ determination, the participants collected stool samples in airtight plastic bags to prevent the ingress of air, then those samples were analyzed within 8 hours after collection. One gram of feces of each participant was weighed and diluted in sterile deionized water for $\mathrm{pH}$ analysis. One gram of feces of each participant was also weighed and diluted in $9 \mathrm{~mL}$ of $0.31 \mathrm{mM}$ phosphate buffer. From this dilution $\left(10^{-1}\right)$, decimal dilutions were performed up to $10^{-7}$ and $100 \mu \mathrm{L}$ of each dilution was spread-plated on selective medium for bifidobacteria BIM-25(20). The plates were incubated at $37^{\circ} \mathrm{C}$ for 72 hours under anaerobic conditions (Anaerobac of Probac ${ }^{\circledR}$ ). At a later stage, bacterial population (bifidobacteria) count was calculated as colony forming units (CFU) per gram of fecal sample weight. Gram stain, catalase test, and fructose6-phosphate phosphoketolase test according to Orban and Patterson (2000) ${ }^{(24)}$ were carried out for all types of isolated colonies in order to confirm Bifidobacterium spp genus.

\section{Statistical analysis}

The statistical analysis was performed in the statistical program GraphPad Prism ${ }^{\circledR}$ version 4.0 in 2003. For analysis of data distribution, it was applied the normality test D'Agostino and Pearson Omnibus Normality Test. Non- parametric Student $t$ test was performed and it was adopted the significance level of $95 \%(P<0.05)$.

\section{Ethical Adherence}

This study protocol was approved by Ethics Committee in Human Beings of the Federal University of Santa Catarina (Process: 772, title page: 333218 - May 31, 2010). Adults were enrolled in the study after a written informed consent was obtained.

\section{RESULTS}

Among the 42 healthy control subjects, 21 were female and 21 male, ages between 21 and 58 years, mean 27 years. Among the 14 celiac patients evaluated, ten were female and four male. The mean age was 40 years, but it was analyzed individuals from 12 to 70 years. The majority $(92.8 \%)$ of celiac was white. All celiac (100\%) had confirmation of the diagnosis by small intestine biopsy and the main clinical symptoms of the disease before treatment are described in Table 1.

TABLE 1. Main clinical symptom presented by celiac patients before treatment (celiac group $\mathrm{n}=14$ )

\begin{tabular}{lc}
\hline Symptom & Patients\% \\
\hline Bloating & 21 \\
Diarrhea & 19 \\
Abdominal pain & 16 \\
Anemia & 10 \\
Poor weight gain & 8 \\
Weight loss & 8 \\
Skin lesions & 8 \\
Oral aphthae & 4 \\
Constipation & 4 \\
Asymptomatic & 2 \\
\hline
\end{tabular}

Regarding the stool samples analysis, the macro and the micromorphology of the bifidobacteria colonies were similar in both groups of celiac patients and control that presented in accordance with the characteristics described in the literature ${ }^{(31)}$. The concentration of bifidobacteria in stool samples from celiac disease patients and controls are 
shown in Figure 1. The celiac patients showed significantly smaller amount of CFU of bifidobacteria per gram compared to controls.

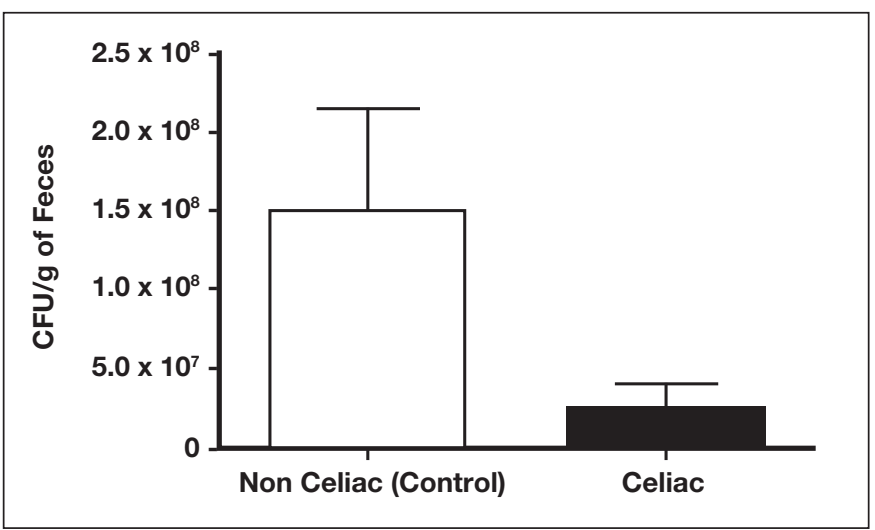

FIGURE 1. Mean of number of colony forming units (CFU) of bifidobacteria per gram of feces of non celiac (controls $n=42$ ) and celiac patients $(\mathrm{n}=14) . * P<0.05$, nonparametric $t$ test.

The average fecal $\mathrm{pH}$ of celiac patients was $7.19 \pm 0.521$ and $7.18 \pm 0.522$ of control subjects. There was no significant difference between groups.

\section{DISCUSSION}

The improvement of screening methods for CD, that became more sensible and specific, allowed the realization of many populational studies, which resulted in revealing celiac disease rates much higher than previously imagined ${ }^{(7)}$. $\mathrm{CD}$ is now considered the most common food intolerance in the world ${ }^{(22)}$. Some studies accomplished in different regions of Brazil, showed prevalence of CD in adults $1 / 123^{(18)}$ and $1 / 214^{(23)}$. The low prevalence can justify the reduced number of patients in the celiac group.

In our study, the largest number of female celiac participants corroborates with the higher prevalence of celiac disease in this sex ${ }^{(15)}$. In addition, in a previous Brazilian study, $97.6 \%$ of celiac patients participants were white ${ }^{(29)}$, which is in agreement with what was observed in our study (92.8\%). Additionally, the main symptoms displayed by celiac patients of this study before treatment was similar to those presented by celiac residents in another region of Brazil ${ }^{(27)}$ and those described in reviews in the literature ${ }^{(7,15,17,22)}$.

In the control group represented just by adults, the composition of the intestinal microbiota at the species level is relatively stable. This stability is reduced by factors as disease and old age. Ageing itself has relatively little effect on the overall gastrointestinal function but, due to the decreased adaptive capacity of the gastrointestinal tract, elderly people may not recover from illnesses as quickly as young adults ${ }^{(32)}$. Some studies have compared the composition of the faecal microbiota of different age groups. Hopkins and collaborators $(2001)^{(12)}$ observed that levels of Bifidobacterium were lower in elderly subjects compared to younger adults, so the results in the celiac group can have suffered some influence by age.

The currently available treatment for $\mathrm{CD}$ consists in dietary exclusion of grains and derivatives containing gluten called as gluten-free diet (GFD) throughout the life $\mathrm{e}^{(17)}$. The compliance to a gluten-free diet is an extremely challenging task, given the problems related to cross-contamination, lack of clear food labeling policies, and poor information on minimal toxic amounts of gliadins for celiac subjects. Even so, patients adhering to a GFD report an improvement in their life quality. The response to therapy is poor in up to $30 \%$ of patients, and dietary non-adherence is the chief cause of persistent or recurrent symptoms ${ }^{(11)}$. While CD serology became negative in $83 \%$ of celiac patients with Marsh lesions on a GFD, mucosal biopsy histology normalized in only $8 \%{ }^{(7)}$. So the complete normalization of duodenal lesions is exceptionally rare in adult celiac patients despite adherence to GFD, symptoms disappearance and negative $\mathrm{CD}$ related serology ${ }^{(7)}$. Because of this, also due to the refractory disease cases and the instability of fecal samples, our number of celiac patients was so small.

Changes in the gut microbiota appear to be involved with a reduction of healthy bacteria and increase in potentially pathogenic species. These changes are generally described in gastrointestinal disorders and infections ${ }^{(30)}$. In this context, there are recommendations for the use of probiotics in necrotizing enterocolitis, childhood diarrhea, inflammatory bowel disease, irritable bowel syndrome, allergy, and to improve the immune response $\mathrm{e}^{(6)}$. The roles of probiotic bacteria for patient's health also led Sanz (2009) ${ }^{(28)}$ to propose the use of probiotics as a nutritional strategy to improve the quality of life of celiac patients.

In this context, our results showed a significantly lower concentration of bifidobacteria in the feces of celiac patients compared with controls, even in FGD, and absence of typical symptoms.

Some studies have also reported that allergic children and patients with atopic diseases are often colonized by a reduced number of bifidobacteria in comparison with healthy subjects, demonstrating a strong correlation between the concentration of bifidobacteria and the host immune disorders ${ }^{(13)}$.

The imbalance in duodenal biota from celiac patients has already described in children ${ }^{(21)}$, and it was also observed a reduction in concentration of species of Bifidobacterium in feces and intestinal biopsy specimens of children ${ }^{(3,5)}$. However, the children's intestinal biota is variable and depends on the type and how long they were breastfeed. Differences in gut microbiota composition exist between breast-fed and formula-fed infants ${ }^{(25)}$. In addition, it is difficult to specify when the intestinal microbiota becomes adult.

As Collado and collaborators ${ }^{(3)}$ observed in celiac children, we observed that celiac adult patients with non active disease showed less amount of bifidobacteria than control group in fecal samples. Therefore, this imbalance appeared to be independent of disease activity and of fecal $\mathrm{pH}$.

The association of $\mathrm{CD}$ with intestinal dysbiosis and the evidences supporting the roles for microbiota and specific 
bacteria in regulating key aspects of innate and acquired immunity have led to the evaluation of possible benefits of potentially probiotics ${ }^{(27)}$.

In this sense, the analysis of the fecal bifidobacteria concentration, better than $\mathrm{pH}$, could be a routine screening in clinical laboratories to evaluate the necessity of dietary supplementation for the use of pre- and/or probiotics on celiac patients.

For fecal analysis of intestinal, contents should be taken in mind variables such as the intestinal motility, the total quantity of ingested fiber, intestinal secretions, such as the production of short chain fatty acids, and duration of dietary intervention. In this sense, the fecal $\mathrm{pH}$ may not accurately reflect the $\mathrm{pH}$ of the colon ${ }^{(8,14)}$.

The colonic fermentation of remaining substrates, held by bacteria such as bifidobacteria, is a complex process. In the cecum and proximal colon the fermentation is higher due to the intense supply of nutrients, production of high shortchain fatty acids, causing a decrease in $\mathrm{pH}^{(5,16)}$, and resulting in rapid bacterial growth. In the distal colon, the substrates are less available, the $\mathrm{pH}$ approaches neutral (6.0 to 7.0) and bacterial growth occurs more slowly ${ }^{(10)}$.

In general, there is an increase in fecal concentration of bifidobacterias and a decrease in fecal $\mathrm{pH}$ after consumption

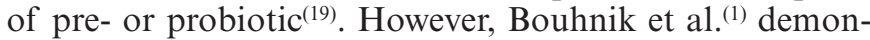
strated that the intake of prebiotics increased the contents of bifidobacteria in feces, but no changes were observed in total amount of aerobic microorganisms, concentrations of bile salts and fecal $\mathrm{pH}$.

Despite the difference in fecal $\mathrm{pH}$ between control and celiac groups was not statistically significant, it is noteworthy that the $\mathrm{pH}$ of control subjects, with higher contents of fecal bifidobcteria, was slightly more acid than the celiac patients, probably due to fermentation performed by these bacteria ${ }^{(2)}$.
At the same time, the results demonstrate that the smallest amount of bifidobacteria in the feces of celiac patients probably is not related to the fecal $\mathrm{pH}$, but with the pathogenesis of DC. Therefore, the relationship between the amount of bifidobacteria and DC should be elucidated. The smallest amount of bifidobacteria in the feces of celiac might be due to the absence of some kind of food that stimulates their growth. Or due to the intestinal inflammatory process that can be present even in celiacs under GFD, probably due to small contaminations that occur in foods referred as gluten free.

According to all demonstrations of probiotic health benefits ${ }^{(27)}$ bifidobacteria has shown a great therapeutic potential and may improve the prognosis of CD. In this sense, we suggest that the intestinal biota could be evaluated more frequently by laboratory tests and if necessary carry out a dietary supplementation with probiotics or prebiotics to improve the quality of life of celiac patients.

However, more in-depth studies investigating the interrelationships among intestinal bacteria, diet and $C D$ are desperately needed to justify why celiac patients have fewer bifidobacteria in controlled phase of the disease (non-active celiac disease), i.e. under gluten-free diet and no clinical symptoms. For example, more studies are needed in patients with negative biopsy to answer if the biota's imbalance is related to inflammation or villi's damage that are still present in a patient under the GFD, or if it is a consequence of contamination of less than $20 \mathrm{ppm}$ of gluten in diet called gluten free, or if the GFD may be failing to provide substrates required for bifidobacteria's growth. Once the answers to these fundamental questions are available, it should be possible to develop specific dietary recommendations for CD based on modification of the composition or activities of the colon's commensal microbiota.

Golfetto L, Senna FD, Hermes J, Beserra BTS, França FS, Martinello F. Baixa contagem de bifidobactérias em pacientes adultos com doença celíaca, em dieta isenta de glúten. Arq Gastroenterol. 2014,51(2):139-43.

RESUMO - Contexto - A ingestão do glúten é responsável pelos sintomas da doença celíaca, mas outros fatores ambientais também podem influenciar Tem sido mostrado que as cepas do género Bifidobacterium proporcionam proteção contra a resposta inflamatória, lesão da mucosa causada por péptidos da gliadina in vitro. Objetivo - Este estudo foi desenvolvido para comparar as concentrações de bifidobactérias e pH fecal de pacientes com doença celíaca em dieta isenta de glúten e indivíduos controles, a fim de identificar se o desequilíbrio na microbiota fecal ainda permanece durante o tratamento da doença celíaca e, identificar a necessidade de suplementação alimentar com pré ou probióticos. Métodos - Foram analisadas as fezes de 42 indivíduos saudáveis e 14 pacientes com doença celíaca. A contagem de bifidobactérias nas fezes foi feita em meio seletivo BIM-25. A análise microscópica das colônias foi realizada por coloração de Gram. A identificação do género Bifidobacterium foi realizada por determinação de phosphoketolase frutose-6-fosfato. $\mathrm{O}$ pH fecal foi medido usando um medidor de $\mathrm{pH}$. Resultados - As concentrações de bifidobactérias por grama de fezes foi significativamente mais elevada nos indivíduos saudáveis (controles) $\left(1,5 \pm 0,63 \times 10^{8} \mathrm{UFC} / \mathrm{g}\right)$, quando comparada com pacientes com doença celíaca $\left(2,5 \pm 1,5 \times 10^{7} \mathrm{UFC} / \mathrm{g}\right)$. O pH fecal não foi diferente entre pacientes celíacos $(7,19 \pm 0,521)$ e controles $(7,18 \pm 0,522)$. Conclusão - Estes resultados sugerem que, com concentrações inferiores de bifidobactérias, pacientes com doença celíaca tem um desequilíbrio na microbiota intestinal, independentemente do $\mathrm{pH}$, mesmo durante uma dieta isenta de glúten. Este fato poderá favorecer o processo patológico da doença.

DESCRITORES - Bifidobacterium. Microbiota. Concentração de íons de Hidrogênio. Doença celíaca. Dieta livre de glúten. 


\section{REFERENCES}

1. Bouhnik Y, Flourié B, D’Agay-Abensour L, Pochart P, Gramet G, Durand M, Rambaud JC. Administration of transgalacto-oligosaccharides increases fecal bifidobacteria and modifies colonic fermentation metabolism in healthy humans. J Nutr. 1997:127:444-8

2. Búrigo T, Fagundes RLM, Trindade EBSM, Franz HCF. Bifidogenic effect of fructooligosaccharides in the intestinal flora of patients with hematological neoplasia. Rev Nutr 2007;20:491-7.

3. Collado MC, Donat E, Ribes-Koninckx C, Calabuig M, Sanz Y. Imbalances in faecal and duodenal Bifidobacterium species composition in active and non-active coeliac disease. BMC Microbiol. 2008;232:1-9.

4. Davis CD, Milner JA. Gastrointestinal microflora, food components and colon cancer prevention. J Nutr Biochem. 2009;20:743-52.

5. Di Cagno R, Rizzello CG, Gagliardi F, Ricciuti P, Ndagijimana M, Francavilla $\mathrm{R}$, et al. Different fecal microbiotas and volatile organic compounds in treated and untreated children with celiac disease. Appl And Environ Microbiol. 2009;75:3963-71.

6. Floch MH, Walker A, Madsen K, Sanders ME, Macfarlane GT, Flint HJ, et al. Recommendations for probiotic use-2011 update. J Clin Gastroenterol. 2011;45:S168-71.

7. Freeman HJ, Chopra A, Clandinin MT, Thomson ABR. Recent advances in celiac disease. World J Gastroenterol. 2011;17:2259-72.

8. Garro MS, Aguirre L, Savoy de Giori G. Biological activity of Bifidobacterium longum in response to environmental pH. Appl Microbiol Biotechnol. 2006;70:612-7.

9. Ghosh S. Advances in our understanding of the pathogenesis of celiac disease. Can J Gastroenterol. 2011;25:186.

10. Gibson GR, Roberfroid MB. Dietary modulation of human colonic microbiota: introducing the concept of the prebiotics. J Nutr. 1995;125:1401-12.

11. Green PHR, Cellier C. Celiac Disease. N Engl J Med. 2007;357:1731-43.

12. Hopkins MJ, Sharp R, Macfarlane GT. Age And disease related changes in intestinal bacterial populations assessed by cell culture 16S rRNA abundance, and community cellular fatty acid profiles. Gut. 2001;48:198-205.

13. Kalliomäki M, Kirjavainen P, Eerola E, Kero P, Salminen S, Isolauri E. Distinct patterns of neonatal gut microflora in infants in whom atopy was and was not developing. J Allergy Clin Immunol. 2001;107:129-34.

14. Kleessen B, Sykura B, Zunfit HJ, Blaut M. Effect of inulin and lactose on fecal microflora, microbial activity, and bowel habit in elderly constipated persons. Am J Clin Nutr. 1997;65:1397-402.

15. Kneepkens CM, von Blomberg BM. Clinical practice: Coeliac disease. Eur J Pediatr. 2012;16.
16. Leahy SC, Higgins DG, Fitzgerald GF, van Sinderen D. Getting better with bifidobacteria. J Appl Microbiol. 2005;98:1303-15.

17. Lionetti E, Catassi C. New clues in celiac disease epidemiology, pathogenesis, clinical manifestations, and treatment. Int Rev Immunol. 2011;30:219-31.

18. Melo SB, Fernandes MI, Peres LC, Troncon LE, Galvão LC. Prevalence and demographic characteristics of celiac disease among blood donors in Ribeirao Preto State of Sao Paulo, Brazil. Dig Dis Sci. 2006;51:1020-5.

19. Mohan R, Koebnick C, Schildt J, Mueller M, Radke M, Blaut M. Effects of Bifidobacterium lactis $\mathrm{Bb} 12$ supplementation on body weight, fecal $\mathrm{pH}$, acetate, lactate, calprotectin, and IgA in preterm infants. Pediatr Res. 2008;64:418-22.

20. Muñoa FJ, Pares R. Selective medium for isolation and enumeration of Bifidobacterium spp. Appl Environ Microbiol. 1988;54:1715-8.

21. Nadal I, Donat E, Ribes-Koninckx C, Calabuig M, Sanz Y. Imbalance in the composition of the duodenal microbiota of children with celiac disease. J Med Microbiol. 2007;56:1669-74.

22. Nobre SR, Silva T, Pina Cabral JE. Doença Celíaca Revisitada. J Port Gastrenterol. 2007;14:184-93.

23. Oliveira RP. High prevalence of celiac disease in Brazilian blood donor volunteers based on screening by IgA antitissue transglutaminase antibody. Eur J Gastroenterol Hepatol. 2007;19:43-9.

24. Orban JI, Patterson JA. Modification of the phosphoketolase assay for rapid identification of bifidobacteria. J Microbiol Meth. 2000;40:221-4

25. Parracho H, McCartney AL, Gibson GR. Probiotics and prebiotics in infant nutrition. Proc Nutr Soc. 2007;66:405-11.

26. Sanders ME. Impact of probiotics on colonizing microbiota of the gut. J Clin Gastroenterol. 2011;45:S115-9.

27. Sanz Y, De Pama G, Laparra M. Unraveling the ties between celiac disease and intestinal microbiota. Int Rev Immunol. 2011;30:207-18.

28. Sanz Y. Novel perspectives in celiac disease therapy. Mini Rev Med Chem. 2009;9:359-67.

29. Sdepanian VL, Morais MB, Fagundes-Neto U. Celiac disease: clinical characteristics and methods used in the diagnosis of patients registered at the Brazilian Celiac Association. J Pediatr. 2001;131-8.

30. Shanahan F. The colonic microflora and probiotic therapy in health and disease Curr Opin Gastroenterol. 2011;27:61-5.

31. Thitaram SN, Siragusa GR, Hinton A Jr. Bifidobacterium-selective isolation and enumeration from chicken caeca by a modified oligosaccharide antibiotic-selective agar medium. Lett Appl Microbiol. 2005;41:355-60.

32. Tiihonen K, Ouwehand AC, Rautonen N. Human intestinal microbiota and healthy ageing. Ageing Res Rev. 2010;9:107-16. 